\title{
Allogeneic Hematopoietic Stem Cell Transplantation, Especially Haploidentical, May Improve Long-term Survival for Children With High- risk T-cell Acute Lymphoblastic Leukemia in First Complete Remission
}

\section{Yongzhan Zhang}

Peking University People's Hospital https://orcid.org/0000-0003-4713-1553

Lu Bai

Peking University People's Hospital

Xiao-jun Huang

Peking University People's Hospital

Ai-dong Lu

Peking University People's Hospital

Yu Wang

Peking University People's Hospital Jun Wu

Peking University Shougang Hospital

Xiao-hui Zhang

Peking University People's Hospital

\section{Ying-xi Zuo}

Peking University People's Hospital

\section{Lan-ping Xu}

Peking University People's Hospital

Yue-ping Jia

Peking University People's Hospital

\section{Yi-fei Cheng}

Peking University People's Hospital

Le-ping Zhang ( $\square$ zhangleping2020@163.com )

Peking University People's Hospital

Research Article 
Keywords: T-cell acute lymphoblastic leukemia, hematopoietic stem cell transplantation, haploidentical, children, total body irradiation

Posted Date: March 13th, 2021

DOI: https://doi.org/10.21203/rs.3.rs-292582/v1

License: (c) (1) This work is licensed under a Creative Commons Attribution 4.0 International License. Read Full License 


\section{Abstract}

\section{Purpose}

The role of hematopoietic stem cell transplantation (HSCT) for children with high-risk (HR) T- cell acute lymphoblastic leukemia (T-ALL) in first complete remission (CR1) is still under critical discussion. This study explored the hierarchical criteria, prognostic factors of childhood T-ALL, and the role of HSCT, especially haplo-HSCT, for children with HR T-ALL in CR1.

\section{Methods}

Seventy-four pediatric T-ALL patients were included in this study and stratified into low-risk chemotherapy cohort $(n=16)$, high-risk chemotherapy cohort $(n=31)$ and high-risk transplant cohort $(n=24)$.

\section{Results}

Patient prognosis in the high-risk chemotherapy cohort was significantly inferior to the low-risk chemotherapy cohort (5-year overall survival (OS): $51.2 \% \pm 10 \%$ vs. $100 \%, P=0.003$; 5-year event-free survival (EFS): $48.4 \% \pm 9.8 \%$ vs. $93.8 \% \pm 6.1 \%, P=0.01 ; 5$-year cumulative incidence of relapse (CIR): $45.5 \%$ $\pm 0.8 \%$ vs. $6.3 \% \pm 0.4 \%, P=0.043$ ). The 5 -year OS, EFS, and CIR of the high-risk transplant cohort were $77.0 \% \pm 8.3 \%, 77.0 \% \pm 8.3 \%$, and $11.9 \% \pm 0.4 \%$, respectively. When compared to the high-risk chemotherapy cohort, the $P$ values were $0.084,0.041$, and 0.011 , respectively. Minimal residual disease (MRD) reemergence, initial white blood cell (WBC) count, and age $\geq 10$ years were independent risk factors for prognosis.

\section{Conclusions}

HSCT, especially haplo-HSCT, might effectively improve the survival outcomes for HR childhood T-ALL in CR1.

\section{Introduction}

T-cell acute lymphoblastic leukemia, an aggressive malignancy associated with poor prognosis, accounts for $10-15 \%$ of all pediatric ALL cases(Pui, et al 2008, Raetz and Teachey 2016, Teachey and O'Connor 2020 , Teachey and Pui 2019). With the advent of various intensive combination chemotherapy regimens in recent years, the 5-year OS and EFS rates have significantly increased to $71.9 \%-91.4 \%$ and $64 \%-87.8 \%$, respectively for children with T-ALL(Asselin, et al 2011, Hofmans, et al 2019, Karrman and Johansson 2017, Raetz and Teachey 2016, Teachey and Pui 2019, Winter, et al 2018). However, patients with HR childhood T-ALL have shown unsatisfactory long-term OS and EFS of less than 50\%(Dunsmore, et al 2012, Schrappe, et al 2011, Schrauder, et al 2006, Willemse, et al 2002). Allogeneic hematopoietic stem cell transplantation (allo-HSCT) is sometimes recommended for children at CR1 showing HR characteristics and often recommended for patients at second or later CR(Hochberg, et al 2013). But children with T-ALL at CR2 or later CR had significantly worse prognosis even if they were treated with 
HSCT. In the past study in our institution, the 3-year LFS for children with T-ALL at CR2 or later CR was only $26.0 \%$ and 3-year CIR was $56.7 \%(X u$, et al 2016). Few studies have demonstrated that the dismal prognosis of HR childhood T-ALL could be improved with allo-HSCT(Balduzzi, et al 2005, Conter, et al 2014, Schrauder, et al 2006). In the German ALL-Berlin-Frankfurt-Munster (BFM) 90 and 95 studies, the 5year OS and 5-year disease-free survival (DFS) of patients who received HSCT in CR1 was $67 \%$, and patients who treated with chemotherapy alone were $47 \%$ and $42 \%$ respectively(Schrauder, et al 2006). Therefore, a risk-stratified approach to treat childhood T-ALL is warranted. In recent years, haploidentical hematopoietic stem cell transplantation (haplo-HSCT) has become an importantly alternative choice for many T-ALL children undergoing transplantation who could not find a matched related or unrelated donor. Moreover, it has proven to be a safe and effective option at our institution previously(Huang, et al 2006, Liu, et al 2008, Liu, et al 2013, Wang, et al 2012, Xu, et al 2016). To our knowledge, there have been fewer reports on the effects of chemotherapy compared to allo-HSCT, especially haplo-HSCT for HR childhood T-ALL, and the hierarchical criteria for HR groups remain unclear. Thus, this study aimed to explore the hierarchical criteria, prognostic factors of childhood T-ALL, and the role of HSCT, especially haplo-HSCT, for children with HR childhood T-ALL in CR1.

\section{Materials And Methods}

\section{Patients}

The clinical characteristics and outcomes of 77 pediatric patients (aged 1-18 years) with newly diagnosed T-ALL between 1 January 2012 and 30 June 2018 were collected. Patients were divided into different groups as described in Fig. 1. Seventy-four patients received induction chemotherapy while three patients died at the initial stage of treatment. Patients were assigned to two different chemotherapy regimens: the modified ALL-BFM protocol(Xue, et al 2019) or the Chinese Children Leukemia Group (CCLG)-ALL 2008 protocol(Cui, et al 2018). We recommend that patients in the low-risk group choose chemotherapy, and patients in the high-risk group choose bone marrow transplantation. All decisions were based on patient preferences. The study was in accordance with the Declaration of Helsinki and was approved by the Ethics Committee of Peking University People's Hospital. Informed consent was obtained from patients and/or their guardians and donors.

\section{Definition of high-risk group}

The high-risk group was defined by the presence of at least one of the following criteria: (1) failure to achieve CR after induction chemotherapy (d33)(Merli, et al 2019, Schrappe, et al 2012); (2) MRD level $\geq$ $1 \times 10^{-4}$ in bone marrow aspirate three months after initial diagnosis(Hefazi and Litzow 2018, Patrick and Vora 2015, Schrappe, et al 2011, Teachey and O'Connor 2020); (3) age $\geq 10$ years(Merli, et al 2019, Teachey and Pui 2019) and (4) re-emergent MRD.

\section{Definitions and evaluations}


Complete remission was defined as bone marrow (BM) leukemic blasts $<5 \%$ with regenerating hematopoiesis (platelet count $>100 \times 10^{9} / \mathrm{I}$, neutrophils $>1 \times 10^{9} / \mathrm{I}$ ) and no localised leukemic infiltrates. MRD of bone marrow was tested by flow cytometry (FCM) and/or quantitative PCR(Cheng, et al 2013, Parekh, et al 2015, Pui, et al 2017). MRD positivity was defined as FCM $\geq 1 \times 10^{-4}$, including positive detection of other mutated genes (SIL/TAL 1, $\mathrm{t}(\mathrm{v} ; 11 \mathrm{q} 23) / M L L$-rearranged). Relapse was defined as recurrence of $\geq 5 \%$ BM leukemic blasts and/or localized leukemic infiltrates at any site.

Overall survival (OS) was defined as time from diagnosis to death from any cause or the the date of final follow-up. Event-free survival (EFS) was defined as time from diagnosis to relapse, second tumor, death or the date of final follow-up. The cumulative incidence of relapse (CIR) was calculated from CR1 to first relapse.

\section{Transplantation}

After induction therapy and at least 2 rounds of consolidation therapy, patients who achieved CR1 underwent a myeloablative transplant without total body irradiation (TBI) in accordance with their guardians' wishes. The preconditioning regiment for MSD transplants was a modified busulfancyclophosphamide (Bu-Cy) conditioning regiment that included hydroxyurea ( $80 \mathrm{mg} / \mathrm{kg} /$ day, p.o., on day - 10); cytarabine ( $2 \mathrm{~g} / \mathrm{m}^{2} /$ day, i.v., on day - 9); Bu (3.2 mg/kg/day, i.v., on days - 8 to -6); Cy (1.8 $\mathrm{g} / \mathrm{m}^{2} /$ day, i.v., on days -5 to -4 ); and methyl-N-(2-chloroethyl)-N-cyclohexyl-N-nitrosourea (Me-CCNU, 250 $\mathrm{mg} / \mathrm{kg} /$ day, p.o., on day -3). The preconditioning regiment for haplo-transplants consisted of cytarabine $\left(4 \mathrm{~g} / \mathrm{m}^{2} /\right.$ day, i.v., on days - 10 to -9); Bu, Cy, Me-CCNU were same as above; and anti-thymocyte immunoglobulin (ATG, $2.5 \mathrm{mg} / \mathrm{kg} /$ day, i.v., on days - 5 to -2). Granulocyte colony-stimulating factor (GCSF) was provided to all transplant recipients to mobilize BM cells plus peripheral blood stem cells (PBSC). Short-term methotrexate (MTX), mycophenolate mofetil (MMF) and cyclosporine A (CsA) were provided to all transplant recipients for preventing graft versus host disease (GVHD). Supportive care was previously detailed(Huang, et al 2006, Liu, et al 2008, Liu, et al 2013, Wang, et al 2012, Xu, et al 2016).

\section{Statistics}

The variance analysis, Mann-Whitney $\mathrm{U}$ test, Kruskal-Wallis $\mathrm{H}$ test, chi-square test or Fisher's exact test were used for comparison of clinical characteristics of different groups. The Kaplan-Meier method and Log-rank test were used for survival analysis. CIR was calculated by competing risk analysis. Factors with $P<0.1$ in univariate analysis were adjusted in multivariate analysis by Cox regression model and $P<0.05$ indicated statistical significance. All statistical analyses were primarily conducted using $\mathrm{R}$ software packages (Bell Labs, New Providence, NJ) and SPSS 26.0 (SPSS Inc., Chicago, IL, USA).

\section{Results}

\section{Patient characteristics}


From 1 January 2012 to 30 June 2018, 77 pediatric patients were newly diagnosed with T-ALL. One patient died prior to induction chemotherapy while two other patients died at the initial stage of induction chemotherapy due to pulmonary hemorrhage and heart damage respectively. The median age of remaining 74 patients admitted to this study was 11 years (range, 2-15). The last follow-up was 1 May 2020 and median follow-up time was 51.2 months (range, 22.1-99.3). The clinical characteristics of patients are summarized in Table 1. 
Table 1

Characteristics of all 74 T-ALL patients

\begin{tabular}{|c|c|c|c|c|c|}
\hline Parameter & $\begin{array}{l}\text { All Patients } \\
\text { Cohort } \\
(\mathrm{N}=74)\end{array}$ & $\begin{array}{l}\text { Low-risk } \\
\text { Chemotherapy } \\
\text { Cohort } \\
(n=16)\end{array}$ & $\begin{array}{l}\text { High-risk } \\
\text { Chemotherapy } \\
\text { Cohort } \\
(n=31)\end{array}$ & $\begin{array}{l}\text { High-risk } \\
\text { Transplant } \\
\text { Cohort } \\
(n=27)\end{array}$ & $\mathbf{P}$ \\
\hline Age, yr & & & & & 0.261 \\
\hline Median (range) & $11(2-15)$ & - & $11(3-15)$ & $12(4-15)$ & \\
\hline $\begin{array}{l}\text { Sex, } \\
\text { male/female }\end{array}$ & $52 / 22$ & $10 / 6$ & $21 / 10$ & $21 / 6$ & 0.520 \\
\hline $\begin{array}{l}\text { WBC count, } \\
\times 10^{9} / \mathrm{L}\end{array}$ & & & & & 0.857 \\
\hline Median (range) & $\begin{array}{l}\text { 73.7(1.1- } \\
691.9)\end{array}$ & $72.5(1.8-691.9)$ & $87.6(1.1-614.8)$ & $\begin{array}{l}\text { 60.5(1.4- } \\
629.3)\end{array}$ & \\
\hline Hemoglobin, g/L & & & & & 0.308 \\
\hline Median (range) & $\begin{array}{l}108(40- \\
157)\end{array}$ & $97(59-124)$ & $104(50-146)$ & $\begin{array}{l}114(40- \\
157)\end{array}$ & \\
\hline $\begin{array}{l}\text { Platelet } \\
\text { count, } \times 10^{9} / \mathrm{L}\end{array}$ & & & & & 0.463 \\
\hline Median (range) & $57(8-461)$ & $51(10-399)$ & $75(12-461)$ & $57(8-390)$ & \\
\hline ETP/Non-ETP & $13 / 58$ & $2 / 14$ & $4 / 26$ & $7 / 18$ & 0.361 \\
\hline SIL/TAL1 & & & & & 0.162 \\
\hline Positive/negative & $13 / 59$ & $2 / 14$ & $3 / 26$ & $8 / 19$ & \\
\hline TCR & & & & & 0.364 \\
\hline Positive/negative & $14 / 58$ & $4 / 12$ & $7 / 22$ & $3 / 24$ & \\
\hline WT1 & & & & & 0.288 \\
\hline Positive/negative & $40 / 32$ & $11 / 5$ & $17 / 12$ & $12 / 15$ & \\
\hline $\begin{array}{l}\text { CNSL at Initial } \\
\text { Diagnosis }\end{array}$ & & & & & 0.261 \\
\hline Yes/No & $4 / 70$ & $1 / 15$ & $3 / 28$ & $0 / 27$ & \\
\hline $\begin{array}{l}\text { Chemotherapy } \\
\text { regimen }\end{array}$ & & & & & 0.482 \\
\hline CCLG-ALL-2008 & $37(50 \%)$ & $7(43.8 \%)$ & $14(45.2 \%)$ & $16(59.3 \%)$ & \\
\hline
\end{tabular}




\begin{tabular}{|c|c|c|c|c|c|}
\hline Parameter & $\begin{array}{l}\text { All Patients } \\
\text { Cohort } \\
(\mathrm{N}=74)\end{array}$ & $\begin{array}{l}\text { Low-risk } \\
\text { Chemotherapy } \\
\text { Cohort } \\
(n=16)\end{array}$ & $\begin{array}{l}\text { High-risk } \\
\text { Chemotherapy } \\
\text { Cohort } \\
(n=31)\end{array}$ & $\begin{array}{l}\text { High-risk } \\
\text { Transplant } \\
\text { Cohort } \\
(n=27)\end{array}$ & $\mathbf{P}$ \\
\hline $\begin{array}{l}\text { Modified BFM } \\
\text { protocol }\end{array}$ & $37(50 \%)$ & $9(56.2 \%)$ & $17(54.8 \%)$ & $11(40.7 \%)$ & \\
\hline CR after IT & $66(89.2 \%)$ & $16(100 \%)$ & $28(90.3 \%)$ & $22(81.5 \%)$ & 0.211 \\
\hline \multicolumn{6}{|l|}{$\begin{array}{l}\text { Follow-up } \\
\text { Time(Months) }\end{array}$} \\
\hline Median (range) & $\begin{array}{l}51.2(22.1- \\
99.3)\end{array}$ & $48.1(34.0-88.7)$ & $51.8(22.1-92.3)$ & $\begin{array}{l}54.6(22.2- \\
99.3)\end{array}$ & 0.592 \\
\hline
\end{tabular}

\section{Early treatment response}

Sixty-six patients (89.2\%) achieved CR at the end of induction chemotherapy, and 74 patients (100\%) eventually achieved CR. Early T-cell precursor (ETP) was a risk factor related to CR after induction chemotherapy $(P=0.000)$. Other clinical characteristics such as sex, age, WBC count, SIL/TAL 1 transcript, $T C R$ positive, WT1 positive and central nervous system leukemia (CNSL) at initial diagnosis, had no influence for early treatment response (Table 2 ). 
Table 2

Factors affecting early treatment response at diagnosis

\begin{tabular}{|c|c|c|c|}
\hline Factors & CR/ALL & Chi-square test & $P$ \\
\hline Age, yr & & 0.011 & 1.000 \\
\hline$<10$ & $26 / 29$ & & \\
\hline$\geq 10$ & $40 / 45$ & & \\
\hline Sex & & 1.764 & 0.227 \\
\hline Male & $48 / 52$ & & \\
\hline Female & $18 / 22$ & & \\
\hline WBC count, $\times 10^{9} / \mathrm{L}$ & & 2.926 & 0.132 \\
\hline$<100$ & $37 / 44$ & & \\
\hline$\geq 100$ & $29 / 30$ & & \\
\hline ETP & & 28.856 & 0.000 \\
\hline Yes & $6 / 13$ & & \\
\hline No & $57 / 58$ & & \\
\hline SIL/TAL 1 & & 1.804 & 0.473 \\
\hline Negative & $51 / 59$ & & \\
\hline Positive & $13 / 13$ & & \\
\hline$T C R$ & & 2.038 & 0.476 \\
\hline Negative & $50 / 58$ & & \\
\hline Positive & $14 / 14$ & & \\
\hline WT1 & & 1.596 & 0.433 \\
\hline Negative & $30 / 32$ & & \\
\hline Positive & $34 / 40$ & & \\
\hline CNSL at Initial Diagnosis & & 0.513 & 1.000 \\
\hline Yes & $4 / 4$ & & \\
\hline No & $62 / 70$ & & \\
\hline Chemotherapy regimen & & 0.561 & 0.711 \\
\hline
\end{tabular}

Early treatment response indicates the response at the end of induction therapy. 


\begin{tabular}{|lll|}
\hline Factors & CR/ALL & Chi-square test $P$ \\
\hline CCLG-ALL-2008 & $32 / 37$ \\
\hline Modified BFM protocol & $34 / 37$ \\
\hline Early treatment response indicates the response at the end of induction therapy. \\
\hline
\end{tabular}

\section{Outcomes}

The study process is detailed in Fig. 1. Low-risk chemotherapy, high-risk chemotherapy, and high-risk transplant cohorts included 16, 31 and 27 patients respectively. There are no statistical difference for baseline characteristics among the three cohorts (Table 1).

27 patients were included in the high-risk transplant cohort, 23 received haplo-HSCT and 4 with matched sibling donor. Three of 27 transplant recipients were MRD-positive before HSCT, and the remaining 24 patients were MRD-negative before HSCT. The median time between diagnosis and transplant was 6.4 months (range, 3.4-15.6).

18 patients $(24.3 \%)$ relapsed: 1 (6.3\%) in the low-risk chemotherapy cohort, 14 (45.2\%) in the high-risk chemotherapy cohort, and $3(11.1 \%)$ in the high-risk transplant cohort. The median time of continuous complete remission was 11.55 months (range, 3.9-26.6) in the high-risk chemotherapy cohort and 12.4 months (range, 8-26.5) in the high-risk transplant cohort. 15 patients had hematologic relapse and 3 patients had extramedullary leukemia relapse. 19 patients had re-emergent MRD and the median time of MRD re-emergence was 7.9 months (range, 2.2-25.5). 20 patients had died and the median follow-up time was 15.75 months (range, 8.2-59.9). 16 patients died of relapse (13 in the high-risk chemotherapy cohort and 3 (haplo-HSCT) in the high-risk transplant cohort), 3 (haploidentical) patients died of transplant-related complications, and 1 patient died of severe pneumonia.

The 5 -year OS was $70.2 \% \pm 6.0 \%$ in all 74 patients, $100 \%$ in the low-risk chemotherapy cohort, and $51.2 \%$ $\pm 10 \%$ in the high-risk chemotherapy cohort $(P=0.003$ ) (Fig. $2 A)$. The 5 -year EFS was $67.8 \% \pm 6.0 \%$ in all patients, $93.8 \% \pm 6.1 \%$ in the low-risk chemotherapy cohort, and $48.4 \% \pm 9.8 \%$ in the high-risk chemotherapy cohort ( $P=0.01$ ) (Fig. 2B). The 5-year CIR was $24.7 \% \pm 0.3 \%$ in the overall cohort, $6.3 \% \pm 0.4 \%$ in the low-risk chemotherapy cohort, and $45.5 \% \pm 0.8 \%$ in the high-risk chemotherapy cohort $(P=0.043)$ (Fig. 3A). The 5year OS, EFS, and CIR were $77.0 \% \pm 8.3 \%, 77.0 \% \pm 8.3 \%$, and $11.9 \% \pm 0.4 \%$ for the high-risk transplant cohort, respectively. When compared to the high-risk chemotherapy cohort, the $P$ values were $0.084,0.041$, and 0.011 , respectively. (Figs. 2C, 2D, 3B). We also compared the prognosis of 24 patients in the high-risk transplant cohort who were CR1 and MRD-negative before HSCT with the high-risk chemotherapy cohort (5-year OS: $83.3 \% \pm 7.6 \%$ vs. $51.2 \% \pm 10 \%, P=0.04$; 5 -year EFS: $83.3 \% \pm 7.6 \%$ vs. $48.4 \% \pm 9.8 \%, P=0.018$; 5 year CIR: $4.2 \% \pm 0.2 \%$ vs. $45.5 \% \pm 0.8 \%, P=0.014$ ) (Figs. $2 \mathrm{E}, 2 \mathrm{~F}, 3 \mathrm{C}$ ). The prognosis of haplo-HSCT recipients who were $\mathrm{CR} 1$ and $\mathrm{MRD}$ negative before HSCT in the high-risk transplant cohort were 
compared to the high-risk chemotherapy cohort (5-year OS: $80.0 \% \pm 8.9 \%$ vs. $51.2 \% \pm 10 \%, P=0.093$; 5 -year EFS: $80.0 \% \pm 8.9 \%$ vs. $48.4 \% \pm 9.8 \%, P=0.047 ; 5$-year CIR: $13.9 \% \pm 0.6 \%$ vs. $45.5 \% \pm 0.8 \%, P=0.022$ ).

\section{Factors related to OS, EFS, and CIR}

The univariate analysis of factors for OS, EFS, and CIR are shown in Table 3. MRD re-emergence and initial WBC count were risk factors for OS, EFS, and CIR. Chemotherapy regimen and age significantly influenced OS and EFS, while transplant significantly influenced CIR. Multivariate analysis revealed that MRD re-emergence was an independent risk factor for OS, EFS, and CIR, age was an independent risk factor for OS and EFS, and initial WBC count was an independent risk factor for EFS and CIR (Table 4). 
Table 3

Univariate analysis of factors associated with long-term prognosis in all 74 T-ALL patients

\begin{tabular}{|c|c|c|c|c|c|c|c|}
\hline Factors & $\begin{array}{l}\text { No. of } \\
\text { Cases }\end{array}$ & $\begin{array}{l}\text { 5-Year } \\
\text { OS(\%) }\end{array}$ & $P$ & $\begin{array}{l}\text { 5-Year } \\
\text { EFS(\%) }\end{array}$ & $\mathbf{P}$ & $\begin{array}{l}\text { 5-Year } \\
\text { CIR(\%) }\end{array}$ & $\mathbf{P}$ \\
\hline \multicolumn{8}{|l|}{ Age, yr } \\
\hline$<10$ & 29 & $89.5 \pm 5.7$ & 0.013 & $82.6 \pm 7.1$ & 0.080 & $\begin{array}{l}17.4 \pm \\
0.5\end{array}$ & 0.26 \\
\hline$\geq 10$ & 45 & $59.2 \pm 8.0$ & & $59.5 \pm 7.9$ & & $\begin{array}{l}29.5 \pm \\
0.5\end{array}$ & \\
\hline \multicolumn{8}{|l|}{ Sex } \\
\hline Male & 52 & $71.1 \pm 7.5$ & 0.655 & $69.5 \pm 7.5$ & 0.451 & $\begin{array}{l}21.7 \pm \\
0.3\end{array}$ & 0.37 \\
\hline Female & 22 & $68.2 \pm 9.9$ & & $\begin{array}{l}63.6 \pm \\
10.3\end{array}$ & & $\begin{array}{l}31.8 \pm \\
1.0\end{array}$ & \\
\hline \multicolumn{8}{|c|}{$W B C, \times 10^{9} / L$} \\
\hline$<100$ & 44 & $75.7 \pm 7.7$ & 0.090 & $76.0 \pm 7.6$ & 0.015 & $\begin{array}{l}14.0 \pm \\
0.3\end{array}$ & 0.0064 \\
\hline$\geq 100$ & 30 & $62.8 \pm 8.9$ & & $56.3 \pm 9.1$ & & $\begin{array}{l}40.4 \pm \\
0.9\end{array}$ & \\
\hline \multicolumn{8}{|c|}{ Hemoglobin, g/L } \\
\hline$<100$ & 25 & $80.0 \pm 8.0$ & 0.445 & $76.0 \pm 8.5$ & 0.609 & $\begin{array}{l}20.0 \pm \\
0.7\end{array}$ & 0.73 \\
\hline$\geq 100$ & 43 & $65.7 \pm 8.3$ & & $63.9 \pm 8.2$ & & $\begin{array}{l}26.5 \pm \\
0.5\end{array}$ & \\
\hline \multicolumn{8}{|c|}{$\begin{array}{l}\text { Platelet count, } \\
\times 10^{9} / \mathrm{L}\end{array}$} \\
\hline$<50$ & 29 & $68.4 \pm 8.7$ & 0.345 & $65.1 \pm 8.9$ & 0.327 & $\begin{array}{l}24.5 \pm \\
0.7\end{array}$ & 0.81 \\
\hline$\geq 50$ & 40 & $73.7 \pm 8.0$ & & $71.9 \pm 8.0$ & & $\begin{array}{l}23.0 \pm \\
0.5\end{array}$ & \\
\hline \multicolumn{8}{|l|}{ ETP } \\
\hline Yes & 13 & $\begin{array}{l}50.8 \pm \\
22.2\end{array}$ & 0.846 & $\begin{array}{l}50.8 \pm \\
22.2\end{array}$ & 0.924 & $\begin{array}{l}16.2 \pm \\
1.2\end{array}$ & 0.36 \\
\hline No & 58 & $73.7 \pm 5.8$ & & $70.3 \pm 6.1$ & & $\begin{array}{l}26.2 \pm \\
0.3\end{array}$ & \\
\hline
\end{tabular}




\begin{tabular}{|c|c|c|c|c|c|c|c|}
\hline Factors & $\begin{array}{l}\text { No. of } \\
\text { Cases }\end{array}$ & $\begin{array}{l}\text { 5-Year } \\
\text { OS(\%) }\end{array}$ & $P$ & $\begin{array}{l}\text { 5-Year } \\
\text { EFS(\%) }\end{array}$ & $\mathbf{P}$ & $\begin{array}{l}\text { 5-Year } \\
\text { CIR(\%) }\end{array}$ & $P$ \\
\hline Negative & 59 & $68.9 \pm 7.2$ & 0.829 & $66.0 \pm 7.2$ & 0.703 & $\begin{array}{l}24.2 \pm \\
0.3\end{array}$ & 0.97 \\
\hline Positive & 13 & $\begin{array}{l}76.9 \pm \\
11.7\end{array}$ & & $\begin{array}{l}76.9 \pm \\
11.7\end{array}$ & & $\begin{array}{l}23.1 \pm \\
1.5\end{array}$ & \\
\hline \multicolumn{8}{|l|}{ TCR } \\
\hline Negative & 58 & $71.8 \pm 7.2$ & 0.587 & $68.9 \pm 7.2$ & 0.686 & $\begin{array}{l}22.8 \pm \\
0.3\end{array}$ & 0.64 \\
\hline Positive & 14 & $\begin{array}{l}63.5 \pm \\
13.1\end{array}$ & & $\begin{array}{l}63.5 \pm \\
13.1\end{array}$ & & $\begin{array}{l}29.4 \pm \\
1.7\end{array}$ & \\
\hline \multicolumn{8}{|l|}{ WT1 } \\
\hline Negative & 32 & $68.5 \pm 8.3$ & 0.538 & $62.2 \pm 8.6$ & 0.275 & $\begin{array}{l}28.5 \pm \\
0.7\end{array}$ & 0.39 \\
\hline Positive & 40 & $73.1 \pm 8.4$ & & $73.4 \pm 8.4$ & & $\begin{array}{l}20.5 \pm \\
0.4\end{array}$ & \\
\hline \multicolumn{8}{|c|}{$\begin{array}{l}\text { CNSL at Initial } \\
\text { Diagnosis }\end{array}$} \\
\hline Yes & 4 & $\begin{array}{l}50.0 \pm \\
25.0\end{array}$ & 0.183 & $\begin{array}{l}50.0 \pm \\
25.0\end{array}$ & 0.294 & $\begin{array}{l}50.0 \pm \\
9.0\end{array}$ & 0.19 \\
\hline No & 70 & $71.3 \pm 6.2$ & & $68.8 \pm 6.2$ & & $\begin{array}{l}23.3 \pm \\
0.3\end{array}$ & \\
\hline \multicolumn{8}{|c|}{ CR after IT } \\
\hline Yes & 66 & $73.3 \pm 6.1$ & 0.105 & $70.5 \pm 6.2$ & 0.164 & $\begin{array}{l}23.0 \pm \\
0.3\end{array}$ & 0.36 \\
\hline No & 8 & $\begin{array}{l}46.9 \pm \\
18.7\end{array}$ & & $\begin{array}{l}46.9 \pm \\
18.7\end{array}$ & & $\begin{array}{l}40.6 \pm \\
4.3\end{array}$ & \\
\hline \multicolumn{8}{|c|}{ MRD after IT } \\
\hline Negative & 55 & $71.5 \pm 7.0$ & 0.816 & $68.2 \pm 7.0$ & 0.978 & $\begin{array}{l}25.7 \pm \\
0.4\end{array}$ & 0.59 \\
\hline Positive & 16 & $\begin{array}{l}68.8 \pm \\
11.6\end{array}$ & & $\begin{array}{l}68.8 \pm \\
11.6\end{array}$ & & $\begin{array}{l}18.8 \pm \\
1.0\end{array}$ & \\
\hline \multicolumn{8}{|c|}{ MRD at 3 months } \\
\hline Negative & 63 & $73.4 \pm 6.4$ & 0.163 & $70.4 \pm 6.5$ & 0.299 & $\begin{array}{l}22.5 \pm \\
0.3\end{array}$ & 0.53 \\
\hline Positive & 10 & $\begin{array}{l}60.0 \pm \\
15.5\end{array}$ & & $\begin{array}{l}60.0 \pm \\
15.5\end{array}$ & & $\begin{array}{l}30.0 \pm \\
2.4\end{array}$ & \\
\hline
\end{tabular}




\begin{tabular}{|c|c|c|c|c|c|c|c|}
\hline Factors & $\begin{array}{l}\text { No. of } \\
\text { Cases }\end{array}$ & $\begin{array}{l}\text { 5-Year } \\
\text { OS(\%) }\end{array}$ & $\mathbf{P}$ & $\begin{array}{l}\text { 5-Year } \\
\text { EFS(\%) }\end{array}$ & $\mathbf{P}$ & $\begin{array}{l}\text { 5-Year } \\
\text { CIR(\%) }\end{array}$ & $\mathbf{P}$ \\
\hline \multicolumn{8}{|c|}{ MRD re-emergence } \\
\hline Yes & 19 & $\begin{array}{l}46.8 \pm \\
11.6\end{array}$ & 0.005 & $\begin{array}{l}42.1 \pm \\
11.3\end{array}$ & 0.002 & $\begin{array}{l}57.9 \pm \\
1.4\end{array}$ & 0.00041 \\
\hline No & 55 & $78.2 \pm 6.9$ & & $76.5 \pm 7.0$ & & $\begin{array}{l}12.9 \pm \\
0.2\end{array}$ & \\
\hline \multicolumn{8}{|l|}{$\begin{array}{l}\text { Chemotherapy } \\
\text { regimen }\end{array}$} \\
\hline CCLG-ALL-2008 & 37 & $82.4 \pm 6.6$ & 0.046 & $80.3 \pm 6.7$ & 0.060 & $\begin{array}{l}17.0 \pm \\
0.4\end{array}$ & 0.11 \\
\hline $\begin{array}{l}\text { Modified BFM } \\
\text { protocol }\end{array}$ & 37 & $60.1 \pm 8.6$ & & $57.6 \pm 8.6$ & & $\begin{array}{l}32.5 \pm \\
0.6\end{array}$ & \\
\hline \multicolumn{8}{|l|}{ Transplant } \\
\hline Yes & 27 & $77.0 \pm 8.3$ & 0.505 & $77.0 \pm 8.3$ & 0.272 & $\begin{array}{l}11.9 \pm \\
0.4\end{array}$ & 0.063 \\
\hline No & 47 & $66.1 \pm 8.3$ & & $62.3 \pm 8.3$ & & $\begin{array}{l}32.0 \pm \\
0.5\end{array}$ & \\
\hline
\end{tabular}

Table 4

Multivariate analysis of factors associated with long-term prognosis in all 74 T-ALL patients

\begin{tabular}{|c|c|c|c|c|c|c|}
\hline & OS & & EFS & & CIR & \\
\hline Variable & $\mathrm{HR}(95 \% \mathrm{Cl})$ & $\mathrm{P}$ & $\mathrm{HR}(95 \% \mathrm{Cl})$ & $\mathrm{P}$ & $\mathrm{HR}(95 \% \mathrm{Cl})$ & $P$ \\
\hline Age $\geq 10 y r$ & $\begin{array}{l}5.025(1.463- \\
17.26)\end{array}$ & 0.010 & $\begin{array}{l}2.859(1.044- \\
7.824)\end{array}$ & 0.041 & & \\
\hline $\begin{array}{l}W B C \geq \\
100 \times 10^{9} / L\end{array}$ & $\begin{array}{l}1.836(0.746- \\
4.520)\end{array}$ & 0.186 & $\begin{array}{l}2.570(1.086- \\
6.081)\end{array}$ & 0.032 & $\begin{array}{l}3.742(1.5829- \\
9.16)\end{array}$ & 0.0039 \\
\hline $\begin{array}{l}\text { MRD re- } \\
\text { emergence }\end{array}$ & $\begin{array}{l}2.925(1.175- \\
7.280)\end{array}$ & 0.021 & $\begin{array}{l}3.323(1.379- \\
8.007)\end{array}$ & 0.007 & $\begin{array}{l}5.910(2.1008- \\
16.63)\end{array}$ & 0.00076 \\
\hline $\begin{array}{l}\text { CCLG-ALL- } \\
2008\end{array}$ & $\begin{array}{l}0.427(0.158- \\
1.154)\end{array}$ & 0.094 & $\begin{array}{l}0.547(0.214- \\
1.401)\end{array}$ & 0.209 & & \\
\hline Transplant & & & & & $\begin{array}{l}0.292(0.0835- \\
1.02)\end{array}$ & 0.053 \\
\hline
\end{tabular}

\section{Discussion}


In recent years, high-dose and multi-agent chemotherapy regimens have improved the outcomes of childhood T-ALL. The 5-year OS and EFS of 74 enrolled patients were $70.2 \% \pm 6.0 \%$ and $67.8 \% \pm 6.0 \%$, respectively, which is comparable to reports by other centers(Asselin, et al 2011, Hofmans, et al 2019, Karrman and Johansson 2017, Raetz and Teachey 2016, Teachey and Pui 2019, Winter, et al 2018).

The rate of CR after induction chemotherapy was $89.2 \%$, and ETP was a risk factor related to CR after induction chemotherapy $(P=0.000)$. The AIEOP centers' study confirmed that ETP-ALL had poor early treatment response and ETP-ALL patients obtained favourable outcome due to application of cyclophosphamide, 6-mercaptopurine, and ara-C(Conter, et al 2016). In the COG AALL0434 study, 1144 patients were included and divided into three groups (ETP, near-ETP, and non-ETP). There are no statistical difference of 5-year OS and EFS among the three groups which showed a lack of significance of the ETP immunophenotype in pediatric T-ALL(Hefazi and Litzow 2018).

The prognosis of HR T-ALL remains unsatisfactory(Dunsmore, et al 2012, Schrappe, et al 2011, Schrauder, et al 2006, Willemse, et al 2002). A risk-stratified approach to treat childhood T-ALL is warranted. In childhood ALL, age, WBC, and response to treatment are independent risk factors. However, the prognostic factors are different between B-ALL and T-ALL(Patrick and Vora 2015). Herein, according to existing literature, we considered CR after induction therapy, MRD at 3 months, MRD re-emergence, or age $\geq 10$ years as the hierarchical criteria(Hefazi and Litzow 2018, Merli, et al 2019, Patrick and Vora 2015, Schrappe, et al 2012, Schrappe, et al 2011, Teachey and O'Connor 2020, Teachey and Pui 2019).

Patients with BM leukemic blasts $>25 \%$ after induction chemotherapy, those older than 10 years, or those with T-ALL were considered to be at particular risk(Merli, et al 2019). Failure of induction therapy is rare in pediatric ALL ( $<2 \%$ of patients), but may have a worse outcome(Merli, et al 2019, Schrappe, et al 2012). In our study, eight patients did not achieve CR at the end of induction chemotherapy, and four patients eventually died (three patients died of relapse and one died of intracranial hemorrhage).

Children with T-ALL have poorer tolerance to chemotherapy and have increased extramedullary relapse as a result of that they are generally older than children with B-ALL. This indicates that older age at presentation may lead a worse prognosis for patients with T-ALL(Teachey and Pui 2019). In this study, age $\geq 10$ years was an independent risk factor affecting 5-year OS and EFS, indicating that children older than 10 years of age have worse prognosis and are more likely to experience relapse. In the univariate analysis, the $P$ value of age $\geq 10$ years for EFS showed a downward trend that was not statistically significant, indicating that patients over 10 years of age may have poorer tolerance to chemotherapy and are more likely to experience treatment complications.

Initial WBC count is an important factor affecting ALL prognosis. In successive EORTC-CLG 58881 and 58951 trials, high-risk T-ALL patients were identified based on WBC count at presentation, CNS-positivity, and treatment response(Hofmans, et al 2019). However in the UK trial, UKALL 2003, EFS was inversely related to WBC for B-ALL $(P<0.001)$ but not for T-ALL(Vaitkevičienè, et al 2011). The Nordic Society of Pediatric Hematology and Oncology (Vaitkevičienè, et al 2011) and COG(Hastings, et al 2015) also reported that initial WBC count was not a risk factor for T-ALL patients. In this study, high initial WBC 
count (WBC $\geq 100 \times 10^{9} / \mathrm{L}$ ) was an independent risk factor affecting the 5-year EFS and CIR, indicating that children with a high initial WBC count may be at greater risk of relapse. The 5-year OS was unaffected by this factor, possibly owing to the application of intensive combination chemotherapy and bone marrow transplantation.

In childhood T-ALL, genetic subtypes such as SIL/TAL 1 and $\mathrm{t}(\mathrm{v} ; 11 \mathrm{q} 23) / M L L$-rearranged are not meaningful, but MRD is a significant factor related to long-term outcomes in most cooperative group studies(Teachey and O'Connor 2020, Teachey and Pui 2019). Improved risk stratification eliminated the previous independent prognostic significance of gender and CNSL, whereas MRD level after induction therapy emerged as a risk stratifying feature(Schmiegelow, et al 2010). A large percentage of childhood TALL patients have detectable MRD after induction chemotherapy, however, they could have a favourable outcomes if MRD converts to negative at post-consolidation(Schrappe, et al 2011). In the AIEOP-BFM 2000 trial, the 7-year EFS of childhood T-ALL patients with positive MRD after induction and MRD converting to negative at day 78 was $81 \%$. Conversely, T-ALL patients who were MRD-positive at day 78 had a relatively high 7-year CIR of 45\% and were considered for HSCT at CR1 (Hefazi and Litzow 2018, Patrick and Vora 2015, Schrappe, et al 2011, Teachey and O'Connor 2020). In this study, MRD positivity at 3 months was not an independent risk factor possibly due to the small sample size and the application of HSCT. Furthermore, 10 patients had detected MRD at 3 months. Four patients chose chemotherapy, but three eventually died of relapse. Six patients chose HSCT, but only one died of multiple organ dysfunction failure (MODF). MRD re-emergence was an independent risk factor affecting 5-year OS, EFS, and CIR, indicating that patients with MRD re-emergence during treatment had a relatively high relapse risk which seriously affected the prognosis.

Although intensive combination chemotherapy regimens are now widely used, HSCT is still valuable for treatment of pediatric T-ALL. HSCT should be strongly recommended for childhood T-ALL patients with positive MRD after consolidation(Teachey and O'Connor 2020). It is suggested for patients to undergo HSCT in condition of continuous CR and low-level MRD (United States $₫ 0.1 \%$, United Kingdom $₫ 0.01 \%$ ) (O'Connor, et al 2017, Schrappe, et al 2011, Teachey and O'Connor 2020). In a study, childhood T-ALL patients older than 6 years who received HSCT had a favourable survival compared to those received chemotherapy (5-year EFS of 40-45\% vs. 26\%)(Schrappe, et al 2012). The German ALL-BFM 90 and 95 studies reported that 5 -year DFS was $67 \%$ in the HSCT group compared to $42 \%$ in the chemotherapy group(Schrauder, et al 2006). In the AIEOP ALL 2000 study, children with T-ALL seemingly benefitted from HSCT with a 5-year DFS of $59.7 \%$ (Conter, et al 2014). A prospective study showed that the 5-year DFS rate was $62.2 \%$ in childhood T-ALL patients that were assigned related donor transplantation(Balduzzi, et al 2005). In a previous study at our institution, 35 HR childhood T-ALL patients received haplo-HSCT in CR1, and the 3-year LFS and CIR was $65.7 \%$ and $19.8 \%$ respectively (Xu, et al 2016$)$. Only a portion of TALL patients required HSCT for cure. In this study, the 5-year OS, EFS, and CIR of the low-risk chemotherapy cohort were $100 \%, 93.8 \% \pm 6.1 \%$, and $6.3 \% \pm 0.4 \%$ respectively, with the therapeutic effect exceeding the international level. Patients in high-risk chemotherapy cohort had a significantly worse outcomes that the 5 -year OS, EFS, and CIR were $51.2 \% \pm 10 \%, 48.4 \% \pm 9.8 \%$, and $45.5 \% \pm 0.8 \%$. The $P$ values 
were $0.003,0.01$, and 0.043 respectively when compared to the low-risk chemotherapy cohort. This demonstrated good risk stratification of patients in this cohort. More importantly, the 5-year OS, EFS, and CIR were $77.0 \% \pm 8.3 \%, 77.0 \% \pm 8.3 \%$, and $11.9 \% \pm 0.4 \%$ respectively, for the high-risk transplant cohort. The therapeutic effect exceeded the level of our previous institutional study, which may be due to the improvement of transplantation technology. When compared to the high-risk chemotherapy cohort, the $P$ values were $0.084,0.041$, and 0.011 respectively, validating that HSCT was an effective strategy to reduce relapse and had the tendency to improve long-term survival in childhood HR T-ALL in CR1. We also compared the prognosis of 24 patients in the high-risk transplant cohort who were CR1 and MRDnegative before HSCT versus the high-risk chemotherapy cohort. Patients in the high-risk group in CR1 with undetectable MRD before HSCT had better outcomes compared to patients with detectable MRD before HSCT. When the prognosis of haplo-HSCT recipients who were CR1 and MRD-negative before HSCT in the high-risk transplant cohort was compared to the high-risk chemotherapy cohort, haplo-HSCT tended to improve long-term survival and reduce relapse.

In previous international studies, conditioning regimen was usually based on TBI(Balduzzi, et al 2005, Conter, et al 2014, Schrauder, et al 2006). However, the associated side effects were significant. Recently, HSCT without TBI has been proven effective for childhood ALL(Hamidieh, et al 2017). It has been demonstrated that central nervous system relapse of childhood ALL could be effectively prevented by risk-adjusted chemotherapy without cranial radiotherapy(Patrick and Vora 2015, Pui, et al 2009). Here, patients receiving HSCT with a TBI-free, Bu-based conditioning regimen had a excellent outcomes with a 5 -year OS of $77.0 \% \pm 8.3 \%$ and a low 5 -year CIR rate of $11.9 \% \pm 0.4 \%$.

In conclusion, HSCT (especially haplo-HSCT) without TBI may improve long-term prognosis for children with high-risk T-ALL in CR1. However, this study is limited because it is a nonrandomized retrospective study with a small sample size in a single-center. In addition, two different chemotherapy regimens were applied to patients which may cause bias, however, there were no statistical difference for long-term survival between patients with those two regimens. The results should be further confirmed by prospective, multicentre, randomized controlled clinical trials.

\section{Declarations}

\section{Acknowledgements}

We would like to thank Editage (www.editage.cn) for English language editing.

\section{Author contributions}

Yong-zhan Zhang and Lu Bai analysed data and wrote the manuscript. Jun Wu, Ying-xi Zuo, Yue-ping Jia and Yi-fei Cheng managed patients and performed follow-up. Ai-dong Lu, Yu Wang, Xiao-hui Zhang, Lanping $\mathrm{Xu}$ and Xiao-jun Huang reviewed and revised this manuscript. Le-ping Zhang and Yi-fei Cheng were the principal investigators and designed the research. All authors approved of the submission of final manuscript. 


\section{Compliance with ethical standards}

\section{Conflict of interest}

None.

\section{References}

1. Asselin, B.L., Devidas, M., Wang, C., Pullen, J., Borowitz, M.J., Hutchison, R., Lipshultz, S.E. \& Camitta, B.M. (2011) Effectiveness of high-dose methotrexate in T-cell lymphoblastic leukemia and advancedstage lymphoblastic lymphoma: a randomized study by the Children's Oncology Group (POG 9404). Blood, 118, 874-883.

2. Balduzzi, A., Valsecchi, M.G., Uderzo, C., De Lorenzo, P., Klingebiel, T., Peters, C., Stary, J., Felice, M.S., Magyarosy, E., Conter, V., Reiter, A., Messina, C., Gadner, H. \& Schrappe, M. (2005) Chemotherapy versus allogeneic transplantation for very-high-risk childhood acute lymphoblastic leukaemia in first complete remission: comparison by genetic randomisation in an international prospective study. The Lancet, 366, 635-642.

3. Cheng, S.H., Lau, K.M., Li, C.K., Chan, N.P., Ip, R.K., Cheng, C.K., Lee, V., Shing, M.M., Leung, A.W., Ha, S.Y., Cheuk, D.K., Lee, A.C., Li, C.H., Luk, C.W., Ling, S.C., Hrusak, O., Mejstrikova, E., Leung, Y. \& Ng, M.H. (2013) Minimal residual disease-based risk stratification in Chinese childhood acute lymphoblastic leukemia by flow cytometry and plasma DNA quantitative polymerase chain reaction. PLoS One, 8, e69467.

4. Conter, V., Valsecchi, M.G., Buldini, B., Parasole, R., Locatelli, F., Colombini, A., Rizzari, C., Putti, M.C., Barisone, E., Nigro, L.L., Santoro, N., Ziino, O., Pession, A., Testi, A.M., Micalizzi, C., Casale, F., Pierani, P., Cesaro, S., Cellini, M., Silvestri, D., Cazzaniga, G., Biondi, A. \& Basso, G. (2016) Early T-cell precursor acute lymphoblastic leukaemia in children treated in AIEOP centres with AIEOP-BFM protocols: a retrospective analysis. The Lancet Haematology, 3, e80-e86.

5. Conter, V., Valsecchi, M.G., Parasole, R., Putti, M.C., Locatelli, F., Barisone, E., Lo Nigro, L., Santoro, N., Arico, M., Ziino, O., Pession, A., Testi, A.M., Micalizzi, C., Casale, F., Zecca, M., Casazza, G., Tamaro, P., La Barba, G., Notarangelo, L.D., Silvestri, D., Colombini, A., Rizzari, C., Biondi, A., Masera, G. \& Basso, G. (2014) Childhood high-risk acute lymphoblastic leukemia in first remission: results after chemotherapy or transplant from the AIEOP ALL 2000 study. Blood, 123, 1470-1478.

6. Cui, L., Li, Z.G., Chai, Y.H., Yu, J., Gao, J., Zhu, X.F., Jin, R.M., Shi, X.D., Zhang, L.P., Gao, Y.J., Zhang, R.D., Zheng, H.Y., Hu, S.Y., Cui, Y.H., Zhu, Y.P., Zou, Y., Ng, M.H.L., Xiao, Y., Li, J.H., Zhang, Y.H., He, H.L., Xian, Y., Wang, T.Y., Li, C.K., Wu, M.Y. \& Chinese Children Leukemia, G. (2018) Outcome of children with newly diagnosed acute lymphoblastic leukemia treated with CCLG-ALL 2008: The first nationwide prospective multicenter study in China. Am J Hematol, 93, 913-920.

7. Dunsmore, K.P., Devidas, M., Linda, S.B., Borowitz, M.J., Winick, N., Hunger, S.P., Carroll, W.L. \& Camitta, B.M. (2012) Pilot Study of Nelarabine in Combination With Intensive Chemotherapy in High- 
Risk T-Cell Acute Lymphoblastic Leukemia: A Report From the Children's Oncology Group. Journal of Clinical Oncology, 30, 2753-2759.

8. Hamidieh, A.A., Monzavi, S.M., Kaboutari, M., Behfar, M. \& Esfandbod, M. (2017) Outcome Analysis of Pediatric Patients with Acute Lymphoblastic Leukemia Treated with Total Body Irradiation-Free Allogeneic Hematopoietic Stem Cell Transplantation: Comparison of Patients with and Without Central Nervous System Involvement. Biol Blood Marrow Transplant, 23, 2110-2117.

9. Hastings, C., Gaynon, P.S., Nachman, J.B., Sather, H.N., Lu, X., Devidas, M. \& Seibel, N.L. (2015) Increased post-induction intensification improves outcome in children and adolescents with a markedly elevated white blood cell count $(>/=200 \times 10(9) / I)$ with T cell acute lymphoblastic leukaemia but not B cell disease: a report from the Children's Oncology Group. Br J Haematol, 168, 533-546.

10. Hefazi, M. \& Litzow, M.R. (2018) Recent Advances in the Biology and Treatment of T Cell Acute Lymphoblastic Leukemia. Curr Hematol Malig Rep, 13, 265-274.

11. Hochberg, J., Khaled, S., Forman, S.J. \& Cairo, M.S. (2013) Criteria for and outcomes of allogeneic haematopoietic stem cell transplant in children, adolescents and young adults with acute lymphoblastic leukaemia in first complete remission. Br J Haematol, 161, $27-42$.

12. Hofmans, M., Suciu, S., Ferster, A., Van Vlierberghe, P., Mazingue, F., Sirvent, N., Costa, V., Yakouben, K., Paillard, C., Uyttebroeck, A., Plantaz, D., Plat, G., Simon, P., Millot, F., Poiree, M., van der Werff Ten Bosch, J., Piette, C., Minckes, O., Rohrlich, P., Girard, S., Cave, H., Bertrand, Y. \& De Moerloose, B. (2019) Results of successive EORTC-CLG 58881 and 58951 trials in paediatric T-cell acute lymphoblastic leukaemia (ALL). Br J Haematol, 186, 741-753.

13. Huang, X.J., Liu, D.H., Liu, K.Y., Xu, L.P., Chen, H., Han, W., Chen, Y.H., Wang, J.Z., Gao, Z.Y., Zhang, Y.C., Jiang, Q., Shi, H.X. \& Lu, D.P. (2006) Haploidentical hematopoietic stem cell transplantation without in vitro T-cell depletion for the treatment of hematological malignancies. Bone Marrow Transplantation, 38, 291-297.

14. Karrman, K. \& Johansson, B. (2017) Pediatric T-cell acute lymphoblastic leukemia. Genes Chromosomes Cancer, 56, 89-116.

15. Liu, D., Huang, X., Liu, K., Xu, L., Chen, H., Han, W., Chen, Y., Zhang, X. \& Jiang, Q. (2008) Haploidentical hematopoietic stem cell transplantation without in vitro $T$ cell depletion for treatment of hematological malignancies in children. Biol Blood Marrow Transplant, 14, 469-477.

16. Liu, D.H., Xu, L.P., Liu, K.Y., Wang, Y., Chen, H., Han, W., Zhang, X.H., Yan, C.H., Zhang, Y.Y., Wang, J.Z., Chen, Y.H., Wang, F.R. \& Huang, X.J. (2013) Long-term outcomes of unmanipulated haploidentical HSCT for paediatric patients with acute leukaemia. Bone Marrow Transplant, 48, 1519-1524.

17. Merli, P., Algeri, M., Del Bufalo, F. \& Locatelli, F. (2019) Hematopoietic Stem Cell Transplantation in Pediatric Acute Lymphoblastic Leukemia. Curr Hematol Malig Rep, 14, 94-105.

18. O'Connor, D., Moorman, A.V., Wade, R., Hancock, J., Tan, R.M.R., Bartram, J., Moppett, J., Schwab, C., Patrick, K., Harrison, C.J., Hough, R., Goulden, N., Vora, A. \& Samarasinghe, S. (2017) Use of Minimal 
Residual Disease Assessment to Redefine Induction Failure in Pediatric Acute Lymphoblastic Leukemia. Journal of Clinical Oncology, 35, 660-667.

19. Parekh, C., Gaynon, P.S. \& Abdel-Azim, H. (2015) End of induction minimal residual disease alone is not a useful determinant for risk stratified therapy in pediatric T-cell acute lymphoblastic leukemia. Pediatric Blood \& Cancer, 62, 2040-2043.

20. Patrick, K. \& Vora, A. (2015) Update on biology and treatment of T-cell acute lymphoblastic leukaemia. Current Opinion in Pediatrics, 27, 44-49.

21. Pui, C.-H., Robison, L.L. \& Look, A.T. (2008) Acute lymphoblastic leukaemia. The Lancet, 371, 10301043.

22. Pui, C.H., Campana, D., Pei, D., Bowman, W.P., Sandlund, J.T., Kaste, S.C., Ribeiro, R.C., Rubnitz, J.E., Raimondi, S.C., Onciu, M., Coustan-Smith, E., Kun, L.E., Jeha, S., Cheng, C., Howard, S.C., Simmons, V., Bayles, A., Metzger, M.L., Boyett, J.M., Leung, W., Handgretinger, R., Downing, J.R., Evans, W.E. \& Relling, M.V. (2009) Treating childhood acute lymphoblastic leukemia without cranial irradiation. $N$ Engl J Med, 360, 2730-2741.

23. Pui, C.H., Pei, D., Raimondi, S.C., Coustan-Smith, E., Jeha, S., Cheng, C., Bowman, W.P., Sandlund, J.T., Ribeiro, R.C., Rubnitz, J.E., Inaba, H., Gruber, T.A., Leung, W.H., Yang, J.J., Downing, J.R., Evans, W.E., Relling, M.V. \& Campana, D. (2017) Clinical impact of minimal residual disease in children with different subtypes of acute lymphoblastic leukemia treated with Response-Adapted therapy. Leukemia, 31, 333-339.

24. Raetz, E.A. \& Teachey, D.T. (2016) T-cell acute lymphoblastic leukemia. Hematology Am Soc Hematol Educ Program, 2016, 580-588.

25. Schmiegelow, K., Forestier, E., Hellebostad, M., Heyman, M., Kristinsson, J., Soderhall, S., Taskinen, M., Nordic Society of Paediatric, H. \& Oncology (2010) Long-term results of NOPHO ALL-92 and ALL2000 studies of childhood acute lymphoblastic leukemia. Leukemia, 24, 345-354.

26. Schrappe, M., Hunger, S.P., Pui, C.H., Saha, V., Gaynon, P.S., Baruchel, A., Conter, V., Otten, J., Ohara, A., Versluys, A.B., Escherich, G., Heyman, M., Silverman, L.B., Horibe, K., Mann, G., Camitta, B.M., Harbott, J., Riehm, H., Richards, S., Devidas, M. \& Zimmermann, M. (2012) Outcomes after induction failure in childhood acute lymphoblastic leukemia. N Engl J Med, 366, 1371-1381.

27. Schrappe, M., Valsecchi, M.G., Bartram, C.R., Schrauder, A., Panzer-Grumayer, R., Moricke, A., Parasole, R., Zimmermann, M., Dworzak, M., Buldini, B., Reiter, A., Basso, G., Klingebiel, T., Messina, C., Ratei, R., Cazzaniga, G., Koehler, R., Locatelli, F., Schafer, B.W., Arico, M., Welte, K., van Dongen, J.J., Gadner, H., Biondi, A. \& Conter, V. (2011) Late MRD response determines relapse risk overall and in subsets of childhood T-cell ALL: results of the AIEOP-BFM-ALL 2000 study. Blood, 118, 2077-2084.

28. Schrauder, A., Reiter, A., Gadner, H., Niethammer, D., Klingebiel, T., Kremens, B., Peters, C., Ebell, W., Zimmermann, M., Niggli, F., Ludwig, W.D., Riehm, H., Welte, K. \& Schrappe, M. (2006) Superiority of allogeneic hematopoietic stem-cell transplantation compared with chemotherapy alone in high-risk childhood T-cell acute lymphoblastic leukemia: results from ALL-BFM 90 and 95. J Clin Oncol, 24, 5742-5749. 
29. Teachey, D.T. \& O'Connor, D. (2020) How I treat newly diagnosed T-cell acute lymphoblastic leukemia and T-cell lymphoblastic lymphoma in children. Blood, 135, 159-166.

30. Teachey, D.T. \& Pui, C.-H. (2019) Comparative features and outcomes between paediatric T-cell and Bcell acute lymphoblastic leukaemia. The Lancet Oncology, 20, e142-e154.

31. Vaitkevičienė, G., Forestier, E., Hellebostad, M., Heyman, M., Jonsson, O.G., Lähteenmäki, P.M., Rosthoej, S., Söderhäll, S. \& Schmiegelow, K. (2011) High white blood cell count at diagnosis of childhood acute lymphoblastic leukaemia: biological background and prognostic impact. Results from the NOPHO ALL-92 and ALL-2000 studies. European Journal of Haematology, 86, 38-46.

32. Wang, Y., Liu, D.H., Xu, L.P., Liu, K.Y., Chen, H., Chen, Y.H., Han, W., Zhang, X.H. \& Huang, X.J. (2012) Haploidentical/mismatched hematopoietic stem cell transplantation without in vitro $T$ cell depletion for T cell acute lymphoblastic leukemia. Biol Blood Marrow Transplant, 18, 716-721.

33. Willemse, M.J., Seriu, T., Hettinger, K., d'Aniello, E., Hop, W.C., Panzer-Grumayer, E.R., Biondi, A., Schrappe, M., Kamps, W.A., Masera, G., Gadner, H., Riehm, H., Bartram, C.R. \& van Dongen, J.J. (2002) Detection of minimal residual disease identifies differences in treatment response between T-ALL and precursor B-ALL. Blood, 99, 4386-4393.

34. Winter, S.S., Dunsmore, K.P., Devidas, M., Wood, B.L., Esiashvili, N., Chen, Z., Eisenberg, N., Briegel, N., Hayashi, R.J., Gastier-Foster, J.M., Carroll, A.J., Heerema, N.A., Asselin, B.L., Gaynon, P.S., Borowitz, M.J., Loh, M.L., Rabin, K.R., Raetz, E.A., Zweidler-Mckay, P.A., Winick, N.J., Carroll, W.L. \& Hunger, S.P. (2018) Improved Survival for Children and Young Adults With T-Lineage Acute Lymphoblastic Leukemia: Results From the Children's Oncology Group AALL0434 Methotrexate Randomization. $J$ Clin Oncol, 36, 2926-2934.

35. Xu, Z.L., Huang, X.J., Liu, K.Y., Chen, H., Zhang, X.H., Han, W., Chen, Y.H., Wang, F.R., Wang, J.Z., Wang, Y., Chen, Y., Yan, C.H. \& Xu, L.P. (2016) Haploidentical hematopoietic stem cell transplantation for paediatric high-risk T-cell acute lymphoblastic leukaemia. Pediatr Transplant, 20, 572-580.

36. Xue, Y.J., Cheng, Y.F., Lu, A.D., Wang, Y., Zuo, Y.X., Yan, C.H., Wu, J., Sun, Y.Q., Suo, P., Chen, Y.H., Chen, H., Jia, Y.P., Liu, K.Y., Han, W., Xu, L.P., Zhang, L.P. \& Huang, X.J. (2019) Allogeneic Hematopoietic Stem Cell Transplantation, Especially Haploidentical, May Improve Long-Term Survival for High-Risk Pediatric Patients with Philadelphia Chromosome-Positive Acute Lymphoblastic Leukemia in the Tyrosine Kinase Inhibitor Era. Biol Blood Marrow Transplant, 25, 1611-1620.

\section{Figures}




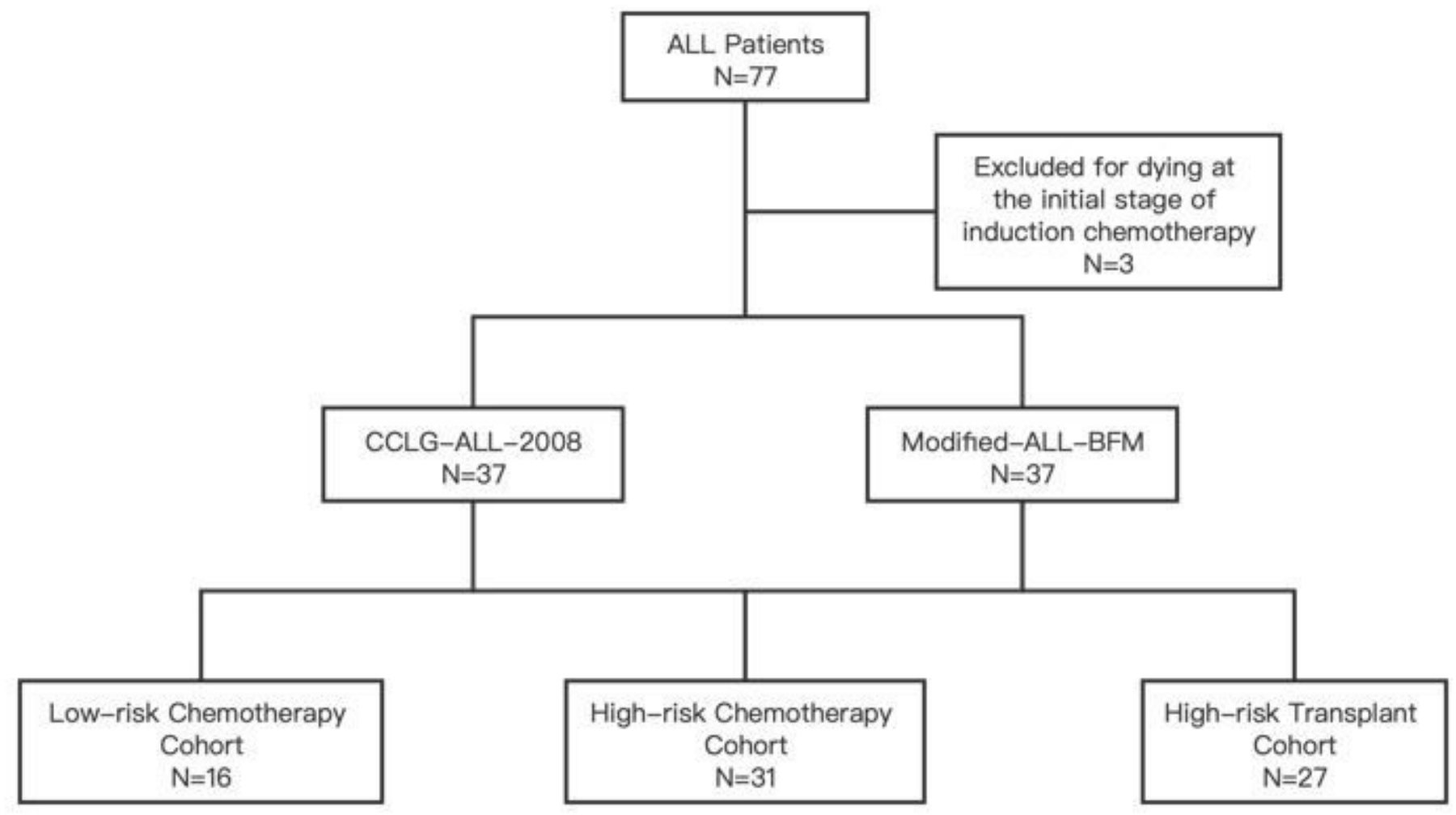

Figure 1

Diagram of all patients included in the study 
A

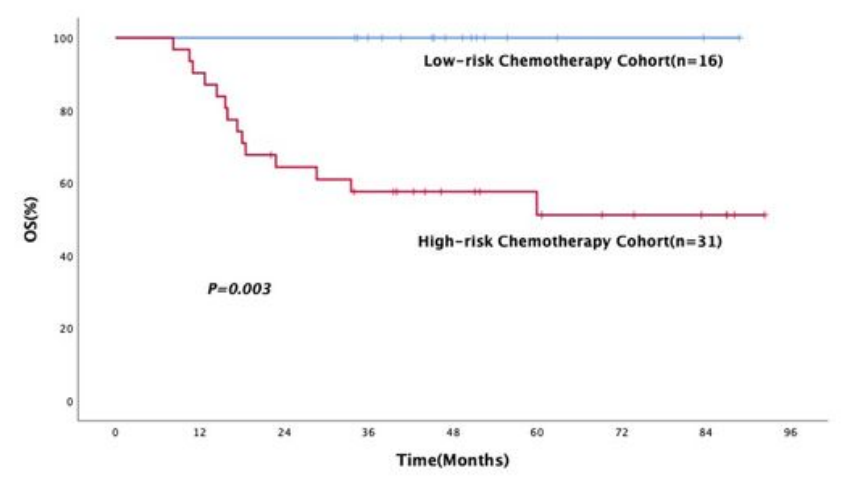

B

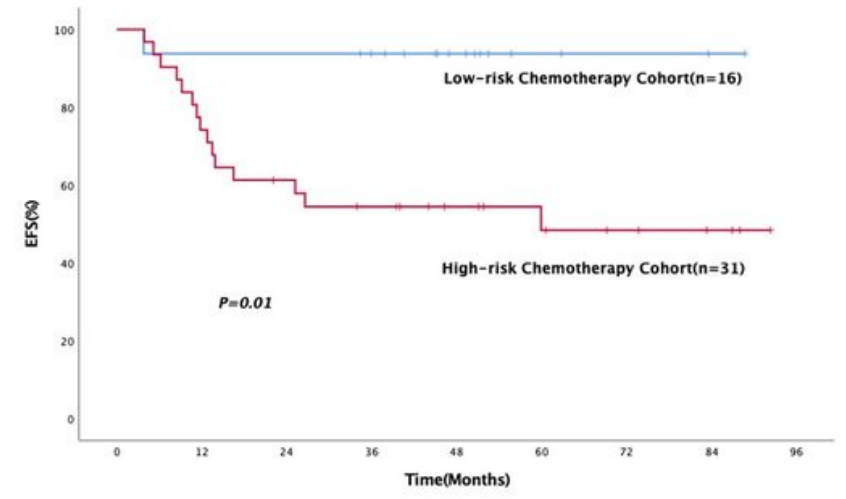

$\mathrm{C}$

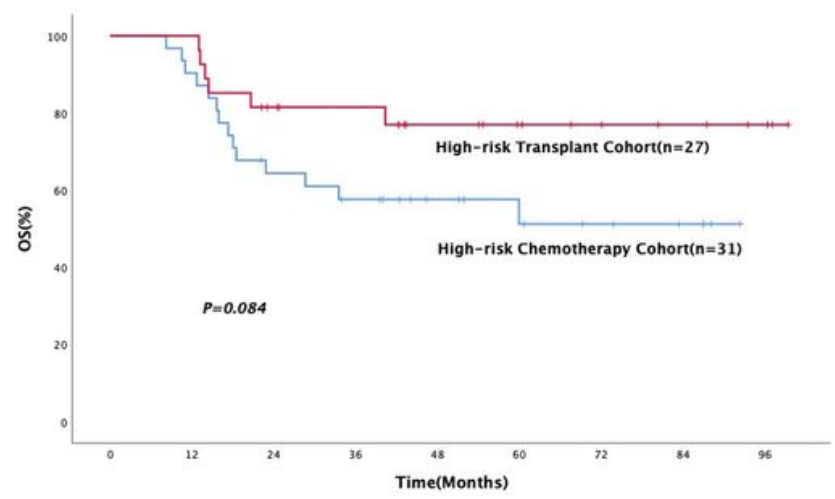

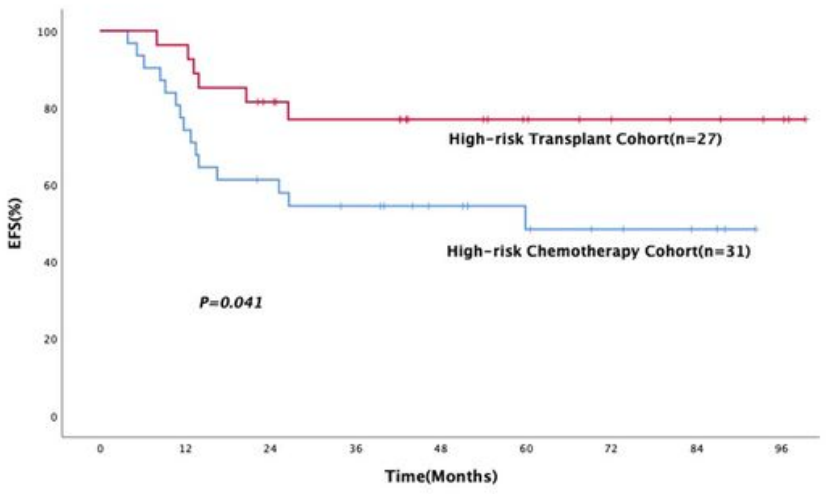

E

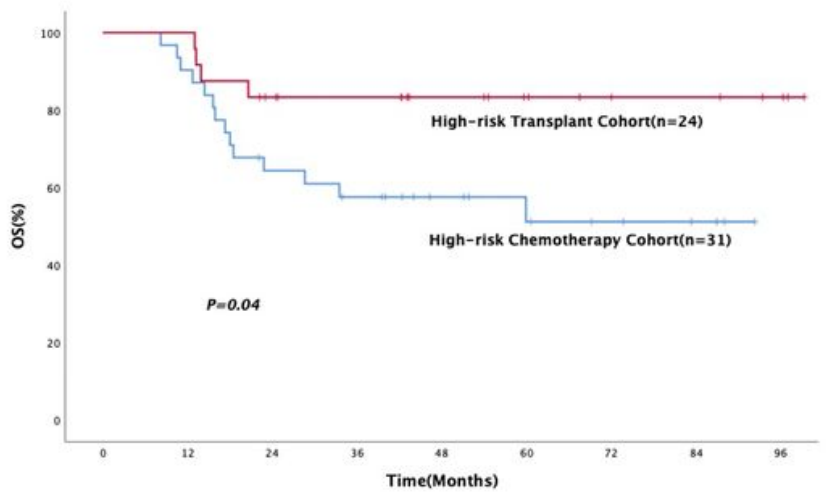

F

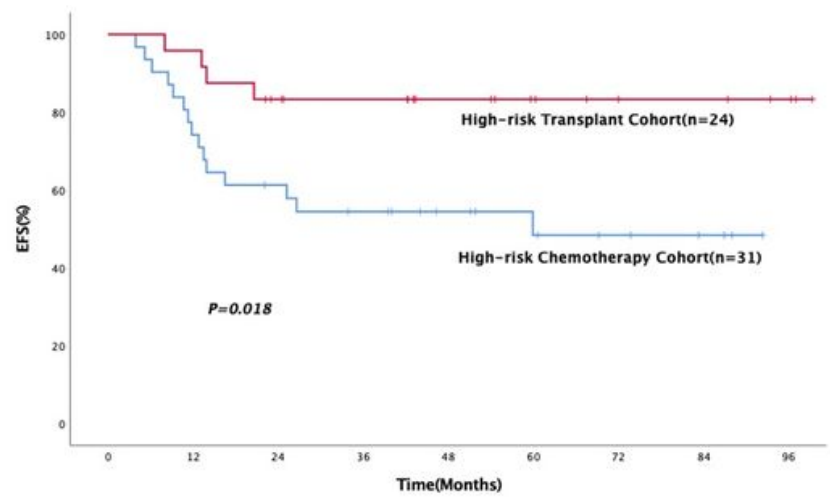

Figure 2

Kaplan-Meier estimates of 5-year outcomes in the three cohorts. (A) OS in low-risk chemotherapy cohort versus high-risk chemotherapy cohort, (B) EFS in low-risk chemotherapy cohort versus high-risk chemotherapy cohort, (C) OS in high-risk chemotherapy cohort versus high-risk transplant cohort, (D) EFS in high-risk chemotherapy cohort versus high-risk transplant cohort, (E) OS in high-risk chemotherapy cohort versus 24 patients of high-risk transplant cohort who were CR1 and MRD negative before HSCT, (F) EFS in high-risk chemotherapy cohort versus 24 patients of high-risk transplant cohort who were CR1 and MRD negative before HSCT. 
A

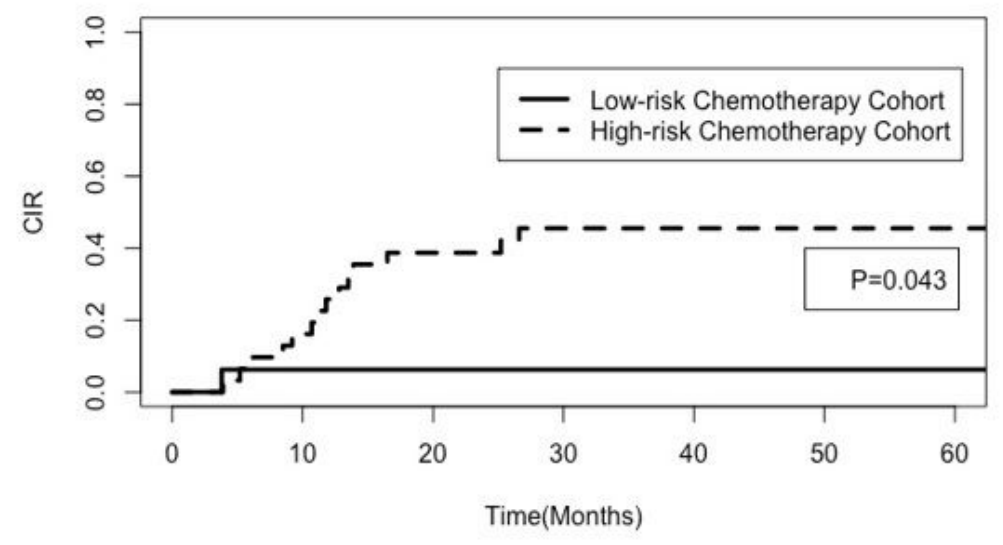

B

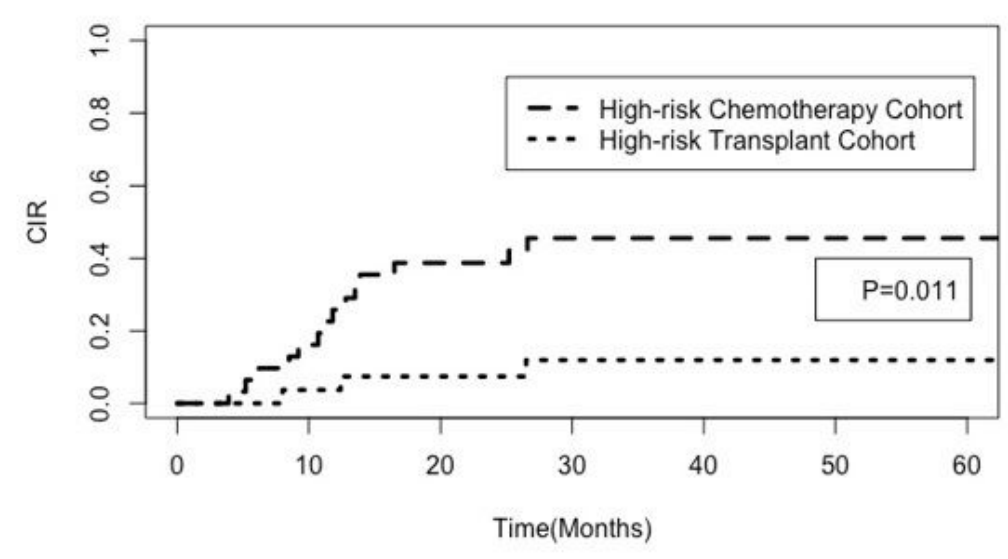

C

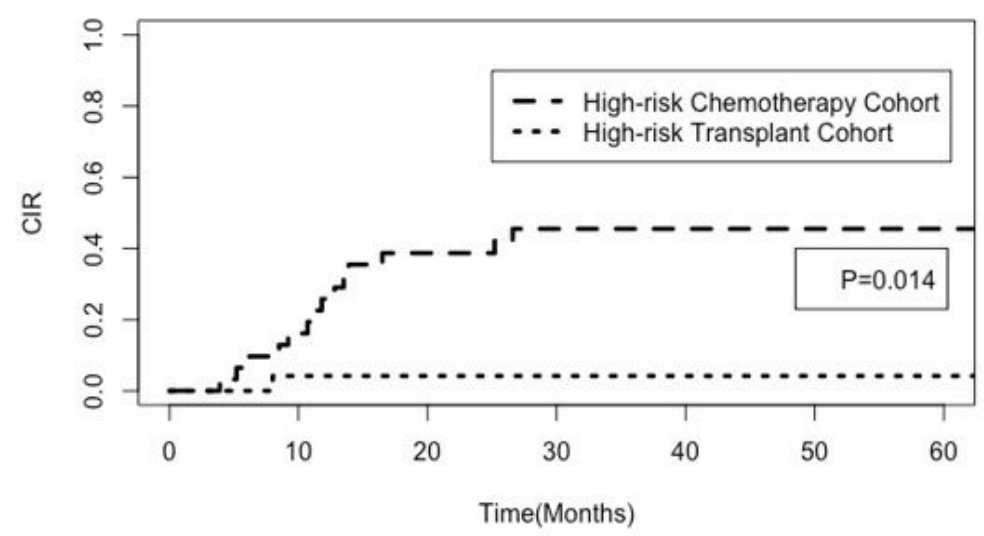

\section{Figure 3}

Kaplan-Meier estimates of 5-year outcomes in the three cohorts. (A) CIR in low-risk chemotherapy cohort versus high-risk chemotherapy cohort, (B) CIR in high-risk chemotherapy cohort versus high-risk transplant cohort, (C) CIR in high-risk chemotherapy cohort versus 24 patients of high-risk transplant cohort who were CR1 and MRD negative before HSCT. 